\title{
SOCIO-ECONOMIC IMPLICATIONS OF UTILIZATION OF INDIGENOUS SPICES IN ORUMBA NORTH, ANAMBRA STATE, NIGERIA
}

\author{
${ }^{1}$ OGBONNA, R. A. AND ${ }^{2}$ M. C. OGBONNA \\ ${ }^{1}$ Home Economics Department, \\ Abia State College of Education (TECH) Arochukwu, Abia state, Nigeria. \\ ${ }^{2}$ National Root Crops Research Institute, Umudike, P.M.B 7006 Umuahia, Abia state, \\ Nigeria \\ E-mail: marcelliuso@yahoo.com GSM: 08055629496, Corresponding author.
}

\begin{abstract}
The study examines socio-economic implications of utilization of indigenous spices in Orumba North, Anambra state, Nigeria. A well designed questionnaire was used in collecting cross sectional data were analysed using descriptive statistical tools. Results showed that $50 \%$ of the women studied were business women and none of the women had zero education but $13 \%$ had higher education. Spices used for food preparation includes; Gongronema latifolium (Utazi), Xylopia dethopica (Uda), Piperguinessnse (Uziza), Penta dethramacropylla (Ukpaka), and Monodora myristica (Ehuru). Others were Ricinus communis (Ogiri isi), Ogiri-okpei, Byrosocurpus dinklayer (Efu), Ocimum gratissimus (Nchanwu), and pepper. These spices are used in preparing soups like bitter leaf soup, Nsala (broth soup), Egwusi (Melon soup), yam portage, African salad and Ncha (sauce) as revealed by 91, 86, 71 and 83\% respectively of the women. Results further showed that smoking, drying, salting and fermentation were preservation methods while the local storage devices used to store processed spices includes air tight container and basket called Ngiga, made from raffia palm or barb wire sheet. Results further showed that some spices have medicinal effect in treating some sicknesses as revealed by 1 and $17 \%$ of the women. A mixture of Uziza and uda, Utazi and Ehuru are used in treating internal wounds, diabetics, cough and catarrh while $6 \%$ of the women used Ogiri-isi spice for suppressing the alcohol taken by over drunken person.
\end{abstract}

Keywords: indigenous spices, utilization, Nigeria

\section{INTRODUCTION}

The basic requirements of life are food, clothing and shelter. Of the three, foods come first. Its importance and the part it plays in sustaining human life cannot be over emphasized. It is for this reason that Joint Food and Agricultural Organization/World Health organization Committee on Nutrition stressed the urgency of the general food, Nutrition and outlook in the world. Spices are aromatic flavouring added to food to enhance it, making it attractive and palatable (Nice, 1995). Without it, the food is just ordinary and unattractive. Spices and flavouring are substances added to food to enhance savoury (Lapedes, 1977). Spices are aromatic vegetable materials used for seasoning. Spices may be derived from any part of plant; leaf (bay), flower bud (cloves), fruit (pigments), bark (cassia), rhizome (turmeric, ginger), root (horse radish), or seed (anise). The skilled in blending of spices in varying proportions will relate to the other ingredients and enhance them (Alais and Linden, 1999). Strange combinations can have amazing and agreeable results for example Nchanwu (Ocimum gratissimus) and Daw-daw (melon paste) in cooking banga soup. The imaginative and judicious use of spices and herbs is one of the most important aspects of successful cooking (Fry, 1982).

There are numerable spices in use in the south eastern Nigeria. Some of these spices are obtained from the wild. If properly harness it could be a money spinning venture like 
ginger, garlic and turmeric. These includes; Monodora myristica (Ehuru), Xylopia dethopica (Uda), Byrosocurpus dinklayer (Efu), Gongronema latifolium (Utazi), Piperguinessnse (Uziza), Ricinus communis (Ogiri isi), Penta dethramacropylla (Ukpaka), Ocimum gratissimus (Nchanwu) among others (Okafor, 1974).. Some of these spices are very medicinal as stressed elsewhere (Law, 1970), for instance; Uda and Uziza are frequently used to prepare food for women after delivery (Davidson, et al., 1979).

Today, there is a growing consciousness about the existence of cheap and nutritious local spices and the need to use them. The consciousness arose due to what the nation encounters in importing expensive foreign foods and spices. There is need for Nigerians to learn to use local spices in the preparation of food based on economic and nutritional point of view. This concern has motivated several researchers on food in some research institutes in Nigeria to find out ways of popularizing some of the local food stuff/spices not widely know and used. A good example of this is the "menu time" and "Maggi kitchen" programmes air by Nigerian Television Authority (NTA) and some states Television stations sponsored by Nestle Food Nigeria.

In Orumba North, Ogiri -isi is frequently used to prepare bitter-leave soup as well as African salad (Gobin, et al., 2001) and so when this is lacking it is neither acceptable nor marketable as pointed out elsewhere (Smith and Minor, 1974). There are several local spices which when process are use, some are been preserve while surpluses are then marketed in the area which perhaps are not documented. Spices are sought in the wide by most women to be traded in the domestic market. Some are been sold fresh while surpluses are preserve using local methods to be traded during off-season. Some women that engage in spice business have gone a little further in diversifying into raising the spices in the farm through credit borrowing. This is to assist them to supply both fresh and dried spice as demand detect. From literature point of view, it has been identified that limited access to credit resources are among the major constraints responsible for declining productivity of agribusiness ventures (Nwaru, 2004). Thus, credit in agribusiness plays a crucial role in enterprise development (Nwagbo, 1989).

Hence, there is need to investigate and identify these local spices and perhaps to know how these spices are use and preserve in the area. Majority of the people who uses these local spices are women, their methods of preservation and storage seem inefficient. Hence, if these spices are properly processed and store with large storage device along with attractive package, documented and promoted, most women may eke out huge income from the sales of these spices. Thus, an attempt is made to study the utilization and preservation of these local spices and flavouring agents and its economic and health implications in Orumba North Local Government Area of Anambra state, Nigeria.

\section{METHODOLOGY}

The study was conducted in Orumba North Local Government Area of Anambra state, Nigeria. It is found along the Awka- Umunze road and is surrounded by the following Umunze, Ekwuluobia, Isu-Ofia, Agulu and Awgbu local government areas. The area is made up of eight communities namely; Nanka, Oko, Amaokpala, Ndike, Omogho, Ufuma, Ajali and Awa. However, for sample selection, a stratified random sampling method was applied in collecting data. The first stage involved random selection of five communities namely Nanka, Oko, Ndike, Ufuma, and Awa. From these communities selected, 70 women were randomly selected, totaling 350 women. They were interviewed by means of well designed questionnaire. Data collected were on their socio- economic characteristics, identification of local spices, uses and preservation etc. The data were analysed using descriptive statistics for ease of understanding and simplicity. 


\section{RESULTS}

\section{Socio- economic characteristics of Respondents}

The Socio- economic characteristics of respondents are presented in Table 1. The results with emphasis to occupation shows that $11 \%$ of the respondents were civil servants, while 29,50 and $10 \%$ respectively, were housewives, business women and students. Based on marital status of the women, $71 \%$ of them were married while $14 \%$ are the Widows, and $10 \%$ were separated. Divorcees accounts for $4 \%$ of the women. From the literacy point of view, none of the women studied had zero education, while $66 \%$ of them attended primary education. The women who attended secondary school were $21 \%$ while $13 \%$ of them entered higher institution.

\section{Knowledge of local spices and type of food use for preparation}

The type of spices known and use for different type of food by women in the area are shown in Table 2. Based on knowledge of local spices in the area, $100 \%$ of the women use Utazi, uda, uziza and pepper respectively. Efu and Ehuru accounts for $34 \%$ of the women who use it while $71 \%$ of the women use Nchanwu and Ogiri-isi respectively, whereas $86 \%$ of them use Ukpaka. Ogiri-Okpei is been use by $43 \%$ of the women. From Table 2, it could be seen that $91 \%$ of the women use local spices in different types of soup but Orah soup is excluded, $86 \%$ of the women use local spices in preparing yam portage while $71 \%$ of them use it in preparing stew/banga stew and local salad, whereas $43 \%$ of them use it in jollof rice preparation. Then $100 \%$ of the women use it in local sauce making which while $83 \%$ of the women use it in preparing Ncha (another type of sauce).

\section{Preservation Methods use by the women}

The preservation methods known and practiced by the women are presented in Table 3 . The results indicated that $71 \%$ of the women preserve Utazi and Ehuru through drying while 71 and $29 \%$ respectively, of the women preserve Uda through smoking and drying. Ninety one percent $(91 \%)$ of the women uses drying to preserve Efu while 31 and $69 \%$ of the women respectively preserve Uziza using drying and smoking methods. Sixty percent $(60 \%)$ of them preserve Nchanwu using drying, whereas $54 \%$ of the women preserve Ukpaka using salting method. Forty -three (43\%) of the respondents preserve Ogiri-isi and Ogiri-okpei through salting, while $17 \%$ of the women preserve them using fermentation process. Pepper is been preserve through drying as been revealed by $43 \%$ of the women.

\section{Local storage methods}

The distribution of the women based on the type of local storage devices use for storage is shown in table 4 . Fourteen percent (14\%) and $43 \%$ of the women respectively, store Utazi in a container and Ngigi while others used it fresh. Hundred percent (100\%) of the women store Uda in Ngiga while Efu is store in container as well as Ngiga by 29 and $34 \%$ of the women respectively. Uziza is store in container and Ngiga by 71 and $29 \%$ of the women respectively. The storage of Nchanwu and Ukpaka respectively, using Ngiga was performed by $60 \%$ of the women while 14 and $46 \%$ respectively of them use container and Ngiga to store. Ehuru is stored in container and Ngiga by 34 and $66 \%$ respectively, of the women. The women stored their pepper using container $(57 \%)$ while $43 \%$ store it using Ngiga. The women who store Ogiri-isi in container were $52 \%$ while $54 \%$ store it in Ngiga.

\section{Medicinal Spices use for Health Matters}

The distribution of women based on the application of medicinal spices is presented in Table 5. The result shows that 7, 17 and $1.14 \%$ respectively of the women use Utazi and Ehuru in the treatment of cough and catarrh while Uziza and Uda are use for the treatment of internal 
wounds and Ukpaka for clearing eyes. Utazi alone accounts for 3\% of the women who use it for curing diabetics while $6 \%$ of the women said that Ogiri-isi is use for suppressing the alcohol for over drunken person.

\section{DISCUSSION}

The higher record shown by the business women with emphasis on occupation is an indication that the local spices in the South Eastern Nigeria are profitable enterprises. These classes of women are those who buy and sells in wholesale and retail as well as those that engage in fast food ventures. Going by the high frequency of these classes of women, they may have borrowed some credits to finance this business as credit is essential from literature point of view for enterprise development (Nwaru and Nnadozie, 2005).

From marital point of view, the higher number of married women as compared to other status is an indication that the women enjoy protections from their husbands. The current existence of some separated and divorced women could be traced to rapid acculturization of the norms and ethics uphold by the African traditional society and partly attributed to harsh economy often experience in most third world countries. There is a higher rate of women who attended primary education when compared to other educational levels which is an indication that those engaged in spices business are out to enhance their well being and that of the society as whole. This argument is supported by the fact that there is zero education recorded in the studied area. The educational status could be of assistance in sourcing for credits in order to enhance their business more efficiently.

Local spices command so much patronage by quite a number of women in the studied area. Spices like Utazi, Uda, Uziza, Nchanwu, Ukpaka, Ogili-isi and pepper are well known by majority of the women which is an indication that there is a strong influence of the forces of demand and supply in the studied area. The rate at which the women depend so much on these spices for daily food preparation could be attributed to it low cost and health implications when compared to the popularity of Efu, Ehuru and Ogili-okpei spices. The spices are suitable for food preparation going by the high turnover of the women who use it in the preparation of bitter leave soup, melon soup, broth soup, yam portage, local sauce, Ncha, Banga stew/soup and local salad. Thus, there is an indication that these spices have economic importance and at such there is need for it massive promotion for economic enhancement of the women. Spices are being preserving to prolong it shelf life. The preservation of Efu, Utazi, and Nchanwu through sun-drying have a lot of economic implications by quite a number of women as it dry faster using this method while spices like Ehuru, Uda and Uziza are similarly been preserve through smoking by quite a lot of women. Most women preserve Ukpaka through salting whereas the low rate of women who preserve Ogili through fermentation is an indication that the use of this spice is restricted to the women in the studied area. There are only two storage devices known to the women such as Nigaga (a locally made rounded basket with lid) and air tight container. The higher frequency of women who store Uda, Nchanwu, Ukpaka, Ehuru and Ogili-isi spices using Nigaga device is an indication that this device has an economic value in the storage of spice. Also most women store Uziza, pepper and Ogili-isi spices using air tight container which show the significance of this device in the studied area. These devices are the best storage techniques available which are low cost but are not commercially oriented in terms of regular market supply of the processed spices. From economic point of view, the aim of every investor according to literature is to maximize profit, maximize sale and utility or combination of both (Olayide, 1982). Hence, there is need for the investors in local spices to diversify their revenue base through credit sourcing in order to purchase large storage device of high capacity. The local spices seem to be in high demand in urban area where the population is more and so having large storage device could be an income booster. 
On the health ground, Uziza in combination with Uda are known to be quite important in treating internal wounds by most women while Utazi in combination with Ehuru have a strong efficacy in suppressing cough and catarrh as indicated by few women. There was also remarkable evidence by few women of using Ogili-isi, utazi and Ukpaka for suppressing the alcohol for person under the influence of alcohol, curing diabetics and clearing eyes respectively. Obviously, if these spices are scientifically process with attractive packaging, it could generate more income to the rural women who are the target group.

\section{CONCLUSION AND RECOMMENDATIONS}

The study was designed to investigate into the utilization and preservation of local spices and flavouring agents in Orumba North local Government Area of Anambra state. Principally the study revealed that business women top the list of women studied and none of the women had zero education but few women had higher education. Spices found and used in the study area for food preparation included Utazi, Uda, Uziza, Ukpaka, Ehuru, Ogiri-isi, Ogiri-okpei, Nchanwu, and pepper. The spices are used in preparing soups like bitter leave soup, Nsala, Egwusi (Melon), yam portage, African salad and Ncha. More so, the women in the study area preserve local spices through smoking, drying, salting and fermentation while the local storage devices used to store processed spices includes air tight container and a locally made basket called Ngiga, made from raffia palm or barb wire sheet. We also found that some of the spices like Uziza and uda, Utazi and Ehuru etc have medicinal effect in treating some diseases.

In view of these findings, measures aim to stimulate the regular use and availability of the spices through appropriate methods all year round include; there should be accessible credits facilities made available to the women through rural development programmes on the part of government to enable them eke out more income, the government should employ some food specialists through the Agricultural Development Programme (ADP) to go into the rural areas to enlighten the women on the best way to cure, preserve and store spices. This perhaps may help in sustaining these spices all through the year or more and also provide income for the women. These local spices are medicinal, therefore programmes aim to promote good health by government is necessary through organized seminar. Some of these spices could serve as foreign exchange earner just like ginger if only more scientific method of processing, preservation and storage could be sought by stakeholders in the food industry and then relay to the women producers who may wish to take up commercial spices production.

Table 1: Distribution based on occupation, marital status and educational levels of the respondents

\begin{tabular}{llcl}
\hline Variable & & Frequency $(\mathrm{n})$ & Percentage $(\%)$ \\
\hline Occupation: & Civil Servant & 40 & 11.00 \\
& House wife & 100 & 29.00 \\
& Business woman & 175 & 50.00 \\
Marital Status: & Student & 35 & 10.00 \\
& Married & 250 & 71.00 \\
& Widow & 50 & 14.00 \\
Separated & 35 & 10.00 \\
Divorced & 15 & 4.00 \\
Educational level: Zero education & 0 & 0.00 \\
Primary education & 230 & 66.00 \\
Secondary education & 75 & 21.00 \\
Higher education & 45 & 13.00
\end{tabular}

Source: survey, 2002 
Table 2: Distribution of women based on the knowledge of local spices and type of food preparation

\begin{tabular}{clll}
\hline Variable & & Frequency $(\mathrm{n})$ & Percentage $(\%)$ \\
\hline Spices: Utazi & 350 & 100.00 \\
& Uda & 380 & 100.00 \\
Efu & 120 & 34.00 \\
Uziza & 350 & 100.00 \\
Nchuanwu & 250 & 71.00 \\
Ukpaka & 300 & 86.00 \\
Ogiri-isi & 250 & 71.00 \\
Ehuru & 120 & 34.00 \\
Ogiri-Okpei & 150 & 43.00 \\
& Pepper & 350 & 100.00 \\
Type of Food: Soups: Bitter leaf, Egwusi, Nsala & 320 & 91.00 \\
& Yam portage & 300 & 86.00 \\
& Stew/ banga stew & 250 & 71.00 \\
& Jollof rice & 150 & 43.00 \\
Local salad & 250 & 71.00 \\
Local source & 350 & 100.00 \\
Ncha & 290 & 83.00 \\
\hline
\end{tabular}

Source: survey, 2002

Table 3: Methods of preservation of local spices based on percentage distribution of women

\begin{tabular}{llll}
\hline Variable & Preservation method & Frequency (n) & Percentage (\%) \\
\hline Utazi & Drying & 250 & 71.00 \\
Uda & Drying & 100 & 29.00 \\
& Smoking & 250 & 71.00 \\
Efu & Drying & 320 & 91.00 \\
Uziza & Drying & 110 & 31.00 \\
& Smoking & 240 & 69.00 \\
Nchanwu & Drying & 210 & 60.00 \\
Ukpaka & Salting & 190 & 54.00 \\
Ogiri-okpei & Drying & 150 & 43.00 \\
& Fermentation & 60 & 17.00 \\
Ehuru & Drying & 100 & 29.00 \\
& Smoking & 320 & 91.00 \\
Pepper & Drying & 150 & 43.00 \\
Ogiri-isi & Salting & 150 & 43.00 \\
& Fermentation & 60 & 17.00 \\
\hline
\end{tabular}

Source: survey, 2002 
Table 4: Distribution of women based on local storage devices use for storage of spices

\begin{tabular}{|c|c|c|c|c|}
\hline \multirow[t]{2}{*}{ Variable } & \multicolumn{2}{|c|}{ Frequency (n) } & \multicolumn{2}{|c|}{ Percentage (\%) } \\
\hline & $\begin{array}{l}\text { Air } \\
\text { container }\end{array}$ & tight Ngiga & Air tight container & Ngiga \\
\hline Utazi & 50 & 150 & 14.00 & 43.00 \\
\hline Uda & & 350 & & 100.00 \\
\hline Efu & 100 & 120 & 29.00 & 34.00 \\
\hline Uziza & 250 & 100 & 71.00 & 29.00 \\
\hline Nchanwu & & 210 & & 60.00 \\
\hline Ukpaka & & 210 & & 60.00 \\
\hline Ogiri-okpei & 50 & 160 & 14.00 & 46.00 \\
\hline Ehuru & 120 & 230 & 34.00 & 66.00 \\
\hline Pepper & 200 & 150 & 57.00 & 43.00 \\
\hline Ogiri-isi & 182 & 189 & 52.00 & 54.00 \\
\hline
\end{tabular}

Source: survey, 2002

Table 5: Distribution of women based on medicinal spices use for health matters

\begin{tabular}{llll}
\hline Variable & Sickness treated/Health issues & Frequency $(\mathrm{n})$ & Percentage $(\%)$ \\
\hline Utazi and Ehuru & Cough and catarrh & 26 & 7.00 \\
Uziza and Uda & Healing wounds & 60 & 17.00 \\
Ukpaka & Clearing eye & 4 & 1.14 \\
Utazi & Curing diabetics & 10 & 3.00 \\
Ogiri-isi & Suppressing alcohol & 20 & 6.00 \\
\hline
\end{tabular}

Source: survey, 2002

\section{REFERENCES}

Alais, C and G. Linden (1999). Food Chemistry. Aspen Puublisers, Inc. Gaithersburg, Maryland

Davidson S, R. Passmore, J.F Brock and A.S Truswell (1979). Human Nutrition and Diabetics. Churchill Livingston Edinburgh, London and New York.

Fry .P (1982).The Good Cooks London Macmillan Press.

Gobin, A.M.L, M.I Uguru and J .Deckers (2001). Oil Crops. Castor. In: R.H. Raemaekers R.H. Crop Production in Tropical Africa. : 725-733. Belgium.

Lapedes, D.N (1977). McGraw- Hill Encyclopia of food Agriculture and Nutrition.

Law, D.O (1970). Herbs for Cooking and Healing. London, W. Foulsham and company ltd.

Nice .J (1995).The complete Book of Homemade preserves. New York Publishers.

Nwagbo, E.C (1989).Impact of Institutional credit on Agriculture in Funtua L.G.A of Katsina state, Nigeria. Samaru Journal of Agricultural Research, vol. 6. :75-86

Nwaru, J.C (2004). Gender and Relative Production Efficiency in Food crop farming in Abia state of Nigeria. The Nigerian Agricultural Journal, Vol.34 :1-10

Nwaru, J.C and B.C.Nnadozie (2005). Impact of credit use on the technical Efficiency of Arable crop farmers in Imo state, Nigeria. Proceeding of Agricultural Society of Nigeria.::382-384

Okafor, J.C (1974). Potentialities of some indigenous fruit tree of Nigeria. Jos Proc. $5^{\text {th }}$ Annual conference of Forestry Association Nigeria

Olayide H.D (1982).Introduction to Agricultural production. Ibadan University Press, Ibadan, Nigeria.

Smith, L.L.W and L.J. (1974). Minor Food Service Science. The Avi Publishing Company Inc. 